\title{
A PROSPECTIVE OBSERVATIONAL STUDY TO COMPARE THE ANTIEMETIC EFFICACY AND SAFETY PROFILE OF TWO COMBINATIONS NAMELY ONDANSETRON-DEXAMETHASONE VERSUS PALONOSETRON-DEXAMETHASONE IN PROPHYLAXIS OF CISPLATIN INDUCED EMESIS
}

\author{
Sneha Prabha M. P1, Anuradha $M^{2}$, Bindu Latha Nair $R^{3}$ \\ ${ }^{1}$ Assistant Professor, Department of Pharmacology, Government Medical College, Kottayam, Kerala. \\ 2Professor \& HOD, Department of Pharmacology, Government Medical College, Idukki, Kerala. \\ 3 Professor \& HOD, Department of Pharmacology, Government Medical College, Kottayam, Kerala.
}

\begin{abstract}
BACKGROUND

Chemotherapy Induced Nausea and Vomiting (CINV) are among the most distressing symptoms for cancer patients and preventing this can lead to a better treatment outcome. Serotonin (5-HT3) receptor antagonists in combination with Dexamethasone remains the mainstay of treatment in chemotherapy-induced emesis. The purpose of this study is to compare the antiemetic efficacy and safety profile of Ondansetron, a first generation 5- $\mathrm{HT}_{3}$ receptor antagonist versus Palonosetron, a second generation 5- $\mathrm{HT}_{3}$ receptor antagonist, both in combination with Dexamethasone, in Cisplatin-induced emesis. This prospective observational study done over a period of 1 year included 120 adult patients scheduled for their first cycle of Cisplatin based chemotherapy regimen in a tertiary care centre of Kerala. These patients were divided into two groups of 60 patients each; group 1 received Ondansetron ( $8 \mathrm{mg}$ ) with Dexamethasone $(8 \mathrm{mg})$ and group 2 received Palonosetron $(0.25 \mathrm{mg})$ with Dexamethasone ( $8 \mathrm{mg}$ ) combinations both intravenously 30 minutes prior to Cisplatin administration. Efficacy of two regimens were compared in terms of complete response rate [CR rate: no emesis and no significant nausea (nausea $<3$ in nausea scale)] between two groups, in acute (0-24 hours) and delayed ( $>24-120$ hours) phases of $1^{\text {st }}$ and $2^{\text {nd }}$ cycles of Cisplatin chemotherapy. Other parameters that were assessed include number of emetic episodes, frequency of nausea and treatment related adverse effects in both the groups. Nausea and vomiting was assessed using Multinational association of supportive care in cancer Antiemetic Tool (MAT). Results were analysed using Chi-square test. Analysis showed that Palonosetron-Dexamethasone combination was found to be more effective in preventing CINV in terms of CR rate and significantly higher responses were seen in delayed phases of both 1 st $(73.3 \%$ vs $50 \%, \mathrm{P}$ value $=0.009)$ and $2^{\text {nd }}(78.3 \%$ vs $55 \%$, P value $=0.007)$ cycles of Cisplatin chemotherapy. When individual parameters were analysed, it was seen that percentage of patients with severe emesis ( $>2$ emetic episodes) and those with severe nausea ( $>7$ in nausea scale) were lower in Palonosetron group in all phases and significant difference were seen in delayed phases of both cycles. The incidence of treatment related adverse effects were mild and there was no significant difference between two groups.
\end{abstract}

\section{KEYWORDS}

Palonosetron, Ondansetron, Dexamethasone, CINV, Cisplatin Induced Emesis.

HOW TO CITE THIS ARTICLE: Prabha SMP, Anuradha M, Bindu Nair BLR. A prospective observational study to compare the antiemetic efficacy and safety profile of two combinations namely ondansetron-dexamethasone versus palonosetrondexamethasone in prophylaxis of cisplatin induced emesis. J. Evolution Med. Dent. Sci. 2016;5(33):1844-1849, DOI: $10.14260 /$ jemds/2016/434

\section{INTRODUCTION}

Chemotherapy-Induced Nausea and Vomiting (CINV) are two of the major factors which contribute to fear, anxiety and apprehension in patients with cancer.1,2 In addition to various medical complications like dehydration, electrolyte imbalance and Mallory-Weiss tears of the oesophagus. ${ }^{1,3}$ It also has considerable economic implications which include costs of antiemetic drugs, additional patient care, extended hospitalization and reduced productivity at work or workdays lost.13,4 Preventing CINV from the start of chemotherapy is important, because successful control in acute phase (0-24 hours after chemotherapy) is associated with reduced incidence of CINV in delayed phase (2-5 days after chemotherapy) and control of emesis in $1^{\text {st }}$ cycle is associated with reduced incidence in subsequent cycles. ${ }^{4,5}$

Financial or Other, Competing Interest: None.

Submission 01-03-2016, Peer Review 31-03-2016,

Acceptance 06-04-2016, Published 25-04-2016.

Corresponding Author:

Dr. Sneha Prabha M. P,

Assistant Professor,

Department of Pharmacology,

C-Block, Government Medical College,

Kottayam-686008, Kerala.

E-mail: drsneha121@gmail.com

DOI: $10.14260 /$ jemds $/ 2016 / 434$
Moreover patients who experience CINV in previous cycle may develop anticipatory nausea and vomiting in later cycles. ${ }^{1,6,7}$ Introduction of serotonin (5- $\left.\mathrm{HT}_{3}\right)$ receptor antagonists in 1990's revolutionized the control of emesis and have now become the cornerstone of therapy for prevention of CINV.8,9,10 First-generation 5- $\mathrm{HT}_{3}$ receptor antagonists, Ondansetron, Granisetron, Dolasetron and Tropisetron in combination with corticosteroids significantly improved the control of acute chemotherapy-induced nausea and vomiting. ${ }^{8,11}$ But delayed nausea and vomiting remains a clinical problem. . $^{11,12}$

The second-generation $5-\mathrm{HT}_{3}$ receptor antagonist, Palonosetron with high receptor binding affinity and long elimination half-life of 40 hours is found to be effective in delayed CINV also.13,14,15 Palonosetron also inhibits substance $\mathrm{P}$ responses in a serotonin-independent manner.13,16,17 Cisplatin provides a model for antiemetic testing, as it is highly emetogenic and found to cause emesis in $99 \%$ of patients without antiemetics. ${ }^{18,19}$

Hence, a comparative study on the antiemetic efficacy and safety profile of two antiemetic regimens, OndansetronDexamethasone combination versus PalonosetronDexamethasone combination in Cisplatin-induced emesis was conducted in our tertiary care hospital. 
The maxim for managing chemotherapy-induced emesis is that, prevention is far more effective than treatment of established nausea and vomiting. ${ }^{20}$ It also improves the patient compliance to chemotherapy and patients can tolerate dose intensified chemotherapy regimens. ${ }^{21}$ With these objectives in mind, we embark upon this study.

\section{METHODOLOGY}

This was a prospective observational study conducted in the Department of Radiotherapy, Govt. Medical College, Calicut, Kerala, during the 1-year period from September 2009 to September 2010. The Institutional Human Ethics Committee approved the study. Based on the data from previous studies, minimum sample size required for our study was calculated to be 53 patients in each group. 22 Expecting noncompliance to the cytotoxic chemotherapy, 60 patients were included in each group and thus a total of 120 patients were included in the study. Written informed consent was obtained from all patients before the study procedure.

\section{Inclusion Criteria}

- Patients of both sexes, between the age groups 20 to 70 years.

- Patients scheduled to receive first course of Cisplatin chemotherapy (70-100 mg/m² BSA) in combination with $5 \mathrm{FU}$ or Paclitaxel or Etoposide.

\section{Exclusion Criteria}

- Presence of nausea and vomiting and the use of other antiemetic agents during the 24 hours prior to administration of chemotherapy.

- Severely debilitated and patients with known brain, hepatic and renal metastasis.

- Presence of other causes of vomiting such as gastrointestinal obstruction.

- Patients in whom the administration of Dexamethasone was contraindicated.

Age and sex matched patients receiving either Ondansetron with Dexamethasone or Palonosetron with Dexamethasone as antiemetic prophylaxis were selected and grouped. Group 1 patients received first dose of Ondansetron (8 $\mathrm{mg}$ ) with Dexamethasone (8 $\mathrm{mg}$ ) injections, 30 minutes prior to Cisplatin administration and was repeated two more times at an interval of 6 hours on the same day. These patients were given oral Ondansetron (8 mg) and Dexamethasone $(8 \mathrm{mg})$ tablets twice daily on $2^{\text {nd }}$ to $5^{\text {th }}$ days. Group 2 patients received only a single injection of Palonosetron (0.25 mg) with Dexamethasone (8 mg), which was given on the first day, 30 minutes prior to Cisplatin administration and it suffice 5 days post-chemotherapy period. These patients were given MAT (Multinational association of supportive care in cancer antiemetic tool).23 questionnaire and were advised to mark,

1. Presence or absence of vomiting.

2. Number of emetic episodes.

3. Presence or absence of nausea.

4. Grade of nausea.

During the $1^{\text {st }}, 2^{\text {nd }}, 3^{\text {rd }}, 4^{\text {th }}$ and $5^{\text {th }}$ days of postchemotherapy period, grade of nausea was marked in a visual analogue scale of 0 to 10 . ( 0 to 3 taken as no significant nausea, 3 to 6 as moderate nausea and 7 to 10 as severe nausea) in the MAT format.
Adverse effects in both the groups, due to antiemetic drugs were also noted during these periods. The same parameters were again assessed in the same patients when they come for $2^{\text {nd }}$ cycle of chemotherapy after 21 days.

Nausea and vomiting in two groups were assessed between two groups in terms of complete response rate [CR rate: no emesis and no significant nausea (nausea $<3$ in nausea scale)]. Other parameters that were assessed are number of emetic episodes, frequency of nausea and treatment related adverse effects between two groups in acute (0-24 hours) and delayed ( $>24-120$ hours) phases of $1^{\text {st }}$ and $2^{\text {nd }}$ cycles of Cisplatin chemotherapy.

Statistical analysis was done using Statistical Package for Social Service (SPSS) software version 16. Chi-square test and Unpaired ' $\mathrm{t}$ ' test were done for the analysis of data. Results were tabulated and significance was expressed according to the $\mathrm{P}$ value, which was kept at a significant level of $<0.05$. Drop out cases were excluded.

\section{RESULTS}

120 patients, 60 patients each in Ondansetron with Dexamethasone (Group I) and Palonosetron with Dexamethasone (Group II) were included in the study. Comparison of demographic characters of patients showed no significant difference between two groups (Figures 1, 2 and 3).

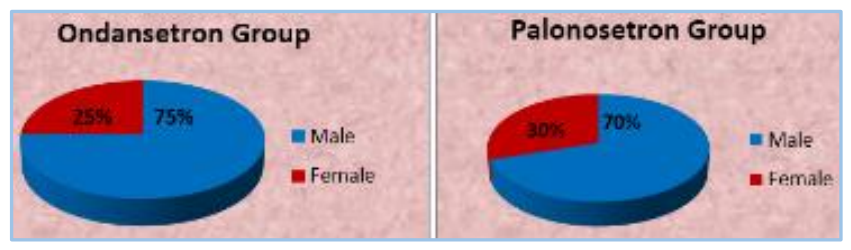

Fig. 1: Comparison of Gender

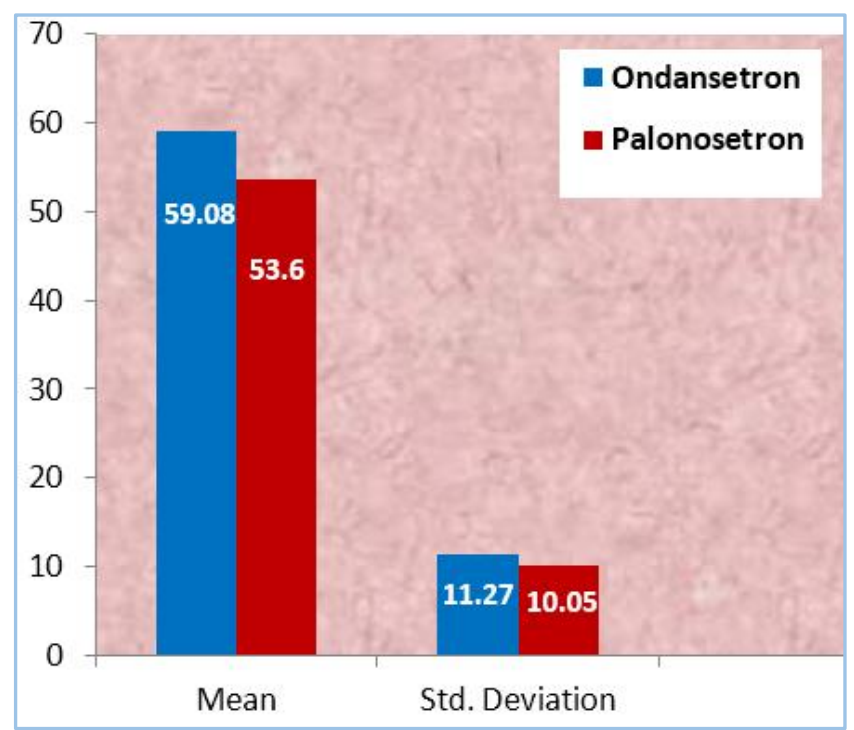

Fig. 2: Comparison of Age

In group I $25 \%$ of patients were males and the mean age was 59.08, whereas in group II $30 \%$ of patients were males and the mean age was 53.6. $\mathrm{P}$ value $=0.540(>0.05)$. Gender distribution between two groups compared using independent ' $\mathrm{t}$ ' test. ( $\mathrm{P}$ value $=0.733$ and $\mathrm{t}$ value $=2.813$ ). There was no significant difference between two groups. 


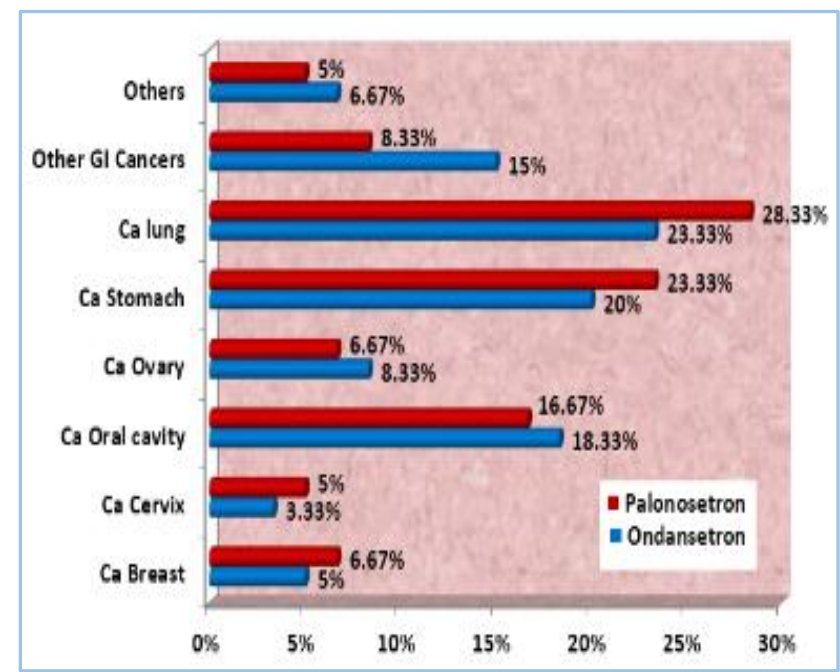

Fig. 3. Comparison of Type of Malignancies

Comparison of type of malignancies between two groups showed no significant difference between two groups ( $P$ value $=0.943$ ). Carcinoma lung was the most common type of malignancy seen followed by carcinoma stomach and carcinoma oral cavity (Figure 3). Two groups were then compared in terms of achieving complete response rate [CR rate: no emesis and no significant nausea (nausea $<3$ in nausea scale)] in acute and delayed phases of $1^{\text {st }}$ and $2^{\text {nd }}$ cycles of chemotherapy.

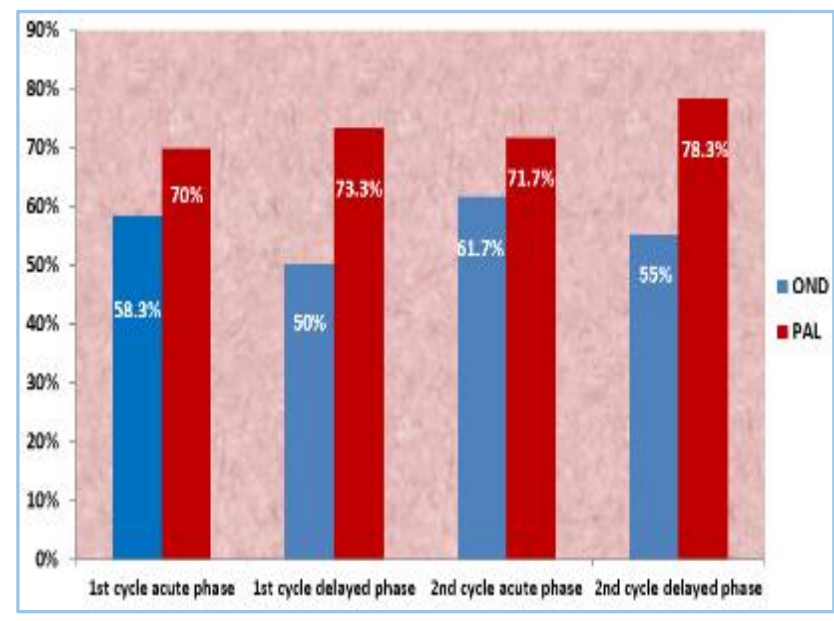

Fig. 4: Complete Response Rate in $1^{\text {st }}$ and $2^{\text {nd }}$ Cycles of Chemotherapy

CR rate was significantly higher in Palonosetron group than in Ondansetron group in delayed phases of both 1 st (73.3\% vs. $50 \%, \mathrm{P}=0.009)$ and $2^{\text {nd }}(78.3 \%$ vs. $55 \%, \mathrm{P}=0.007)$ cycles of chemotherapy. In acute phases even though better responses were seen in Palonosetron group in both the cycles ( $70 \%$ vs. $58.3 \%, \mathrm{P}=0.183$ and $71.7 \%$ vs. $61.7 \%, \mathrm{P}=0.245$ ), the difference was not statistically significant (Figure 4). Among the patients with nausea and vomiting, the severity of emesis in terms of number of emetic episodes and frequency of nausea were also compared between two groups in acute and delayed phases of $1^{\text {st }}$ and $2^{\text {nd }}$ cycles (Figures 5,6 and Tables 1, 2).

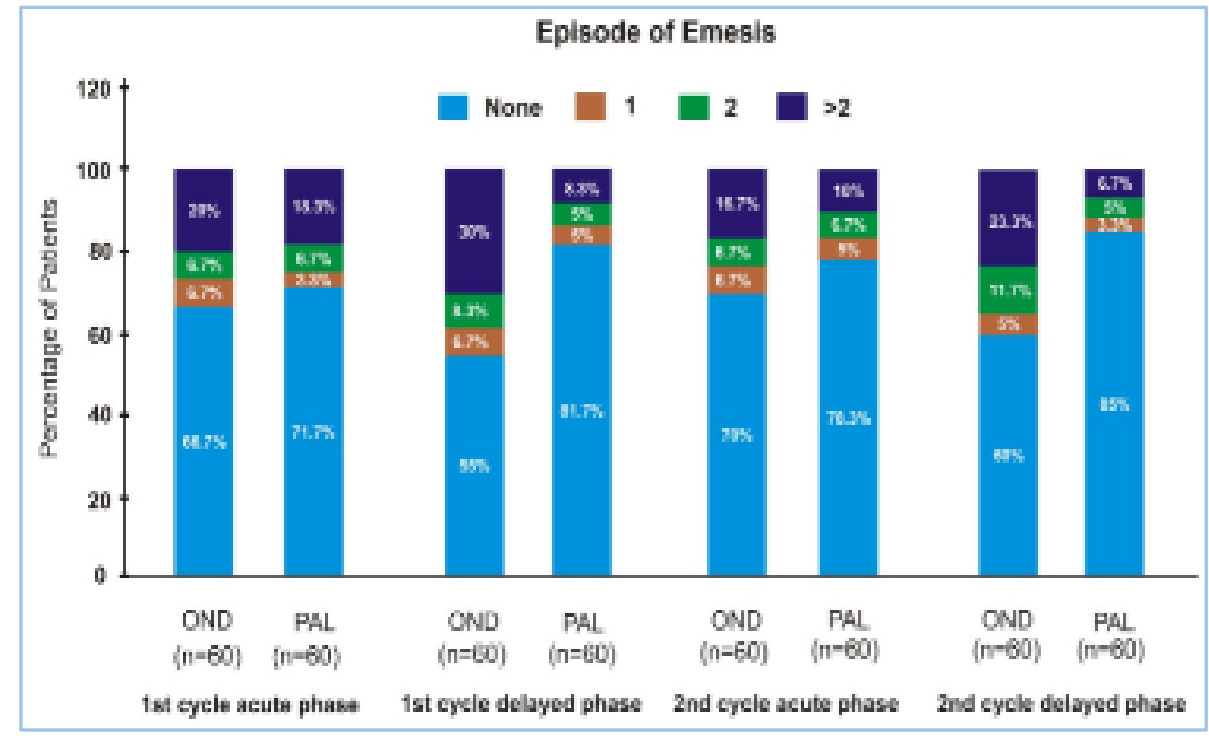

Fig. 5: Episodes of Emesis

\begin{tabular}{|c|c|c|c|c|c|c|}
\hline \multirow{2}{*}{ Cycle } & \multirow{2}{*}{ Phase } & \multirow{2}{*}{ Drugs } & \multicolumn{4}{|c|}{ Number of Emetic Episodes } \\
\hline & & & $\mathbf{0}$ & 1 & 2 & $>2$ \\
\hline \multirow{4}{*}{$1^{\text {st }}$ Cycle } & \multirow{2}{*}{ Acute } & Ondansetron & $40(66.7 \%)$ & $4(6.7 \%)$ & $4(6.7 \%)$ & $12(20 \%)$ \\
\hline & & Palonosetron & $43(71.71 \%)$ & $2(33 \%)$ & $4(6.7 \%)$ & $11(18.31 \%)$ \\
\hline & \multirow{2}{*}{ Delayed } & Ondansetron & $33(55 \%)$ & $4(6.7 \%)$ & $5(8.31 \%)$ & $18(30 \%)$ \\
\hline & & Palonosetron & $49(81.7 \%)$ & $3(5 \%)$ & $3(5 \%)$ & $5(8.3 \%)$ \\
\hline \multirow{4}{*}{ 2nd Cycle } & \multirow{2}{*}{ Acute } & Ondansetron & $42(70 \%)$ & $4(6.7 \%)$ & $4(6.7 \%)$ & $10(16.7 \%)$ \\
\hline & & Palonosetron & 47 (78.3\%) & $3(5 \%)$ & $4(6.7 \%)$ & $6(10 \%)$ \\
\hline & \multirow{2}{*}{ Delayed } & Ondansetron & $36(60 \%)$ & $3(5 \%)$ & $7(11.7 \%)$ & $14(23.3 \%)$ \\
\hline & & Palonosetron & $51(85 \%)$ & $2(3.3 \%)$ & $3(5 \%)$ & $4(6.7 \%)$ \\
\hline & $T a$ & omparison of E & isodes in 1 & d Cycles of & therapy & \\
\hline
\end{tabular}


Emetic episodes were assessed between two groups by calculating percentage of patients with no emesis, 1 episode, 2 episodes and $>2$ episodes of emesis.

Compared to Ondansetron group, percentage of patients with no emesis were much higher in Palonosetron group in all phases and was significantly higher in delayed phases of Palonosetron group in both 1 st ( $81.7 \%$ vs. $55 \%, \mathrm{P}=0.002)$ and 2nd ( $85 \%$ vs. $60 \%, \mathrm{P}=0.002$ ) cycles of chemotherapy. Among the patients with emesis, percentage of patients with severe emesis (with $>2$ emetic episodes) were much lower in Palonosetron group in all phases and significant difference were seen in delayed phases of both the cycles $(8.3 \%$ vs. $30 \%$, $\mathrm{P}=0.003$ and $6.7 \%$ vs. $23.3 \%, \mathrm{P}=0.011$ ).

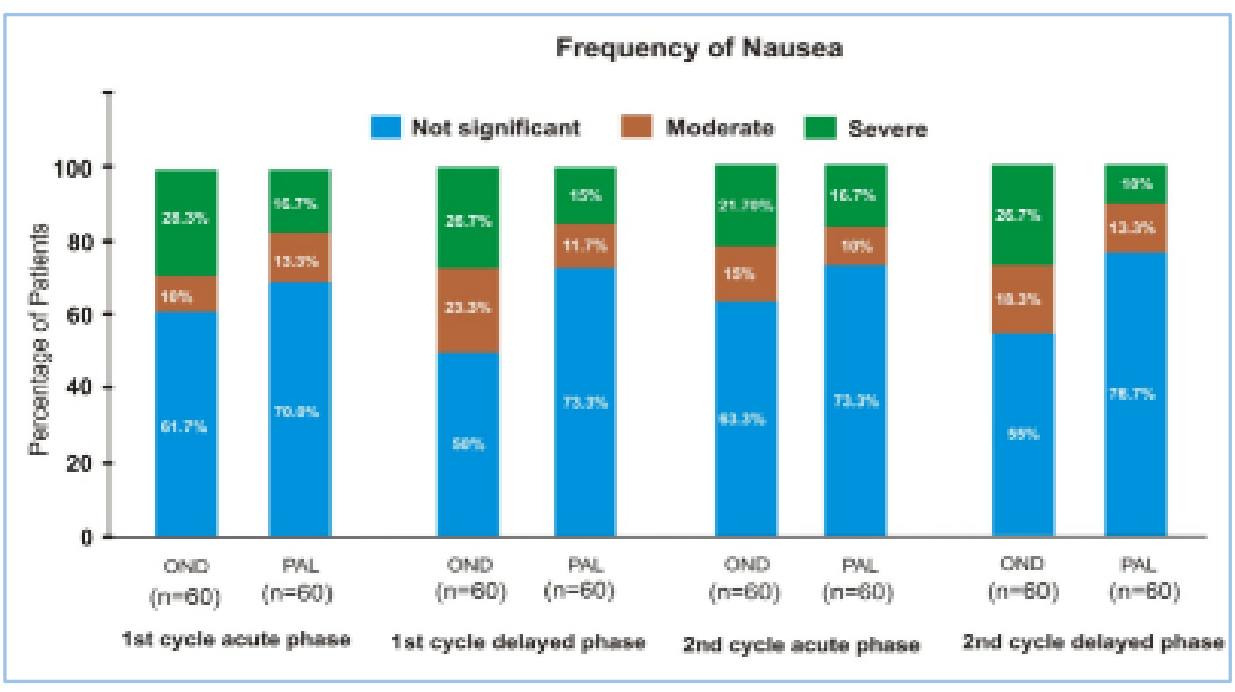

Fig. 6: Frequency of Nausea

\begin{tabular}{|c|c|c|c|c|c|}
\hline \multirow[b]{2}{*}{ Cycle } & \multirow[b]{2}{*}{ Phase } & \multirow[b]{2}{*}{ Drugs } & \multicolumn{3}{|c|}{ Frequency of Nausea } \\
\hline & & & $\begin{array}{c}\text { No Significant } \\
\text { Nausea }\end{array}$ & Moderate & Severe \\
\hline \multirow{4}{*}{$1^{\text {st }}$ Cycle } & \multirow[b]{2}{*}{ Acute } & Ondansetron & $37(61.7 \%)$ & $6(10 \%)$ & $17(28.3 \%)$ \\
\hline & & Palonosetron & $42(70 \%)$ & $8(13.3 \%)$ & $10(16.7 \%)$ \\
\hline & \multirow[b]{2}{*}{ Delayed } & Ondansetron & $30(50 \%)$ & $14(23.3 \%)$ & $16(26.7 \%)$ \\
\hline & & Palonosetron & $44(73.3 \%)$ & $7(11.7 \%)$ & $9(15 \%)$ \\
\hline \multirow{4}{*}{ 2nd Cycle } & \multirow[b]{2}{*}{ Acute } & Ondansetron & $38(63.3 \%)$ & $9(15 \%)$ & $13(21.7 \%)$ \\
\hline & & Palonosetron & $44(73.3 \%)$ & $6(10 \%)$ & $10(16.7 \%)$ \\
\hline & \multirow[b]{2}{*}{ Delayed } & Ondansetron & $33(55 \%)$ & $11(18.3 \%)$ & $16(26.7 \%)$ \\
\hline & & Palonosetron & $46(76.7 \%)$ & $8(13.3 \%)$ & $6(10 \%)$ \\
\hline
\end{tabular}

Frequency of Nausea was also assessed between two groups. Percentage of patients with no significant nausea $(<3$ in nausea scale) were much higher in Palonosetron group in all phases and significant differences were seen in delayed phases of both $1^{\text {st }}(73.3 \%$ vs. $50 \%, P=0.009)$ and $2^{\text {nd }}(76.7 \%$ vs. $55 \%, P=0.012$ ) cycles of chemotherapy. Among the patients with nausea, percentage of patients with severe nausea ( $>7$ in nausea scale) were much lower in Palonosetron group and was significantly lower in delayed phase of $2^{\text {nd }}$ cycle (10\% vs. $26.7 \%, \mathrm{P}=0.028$ ) (Figure 6 and Table 2).

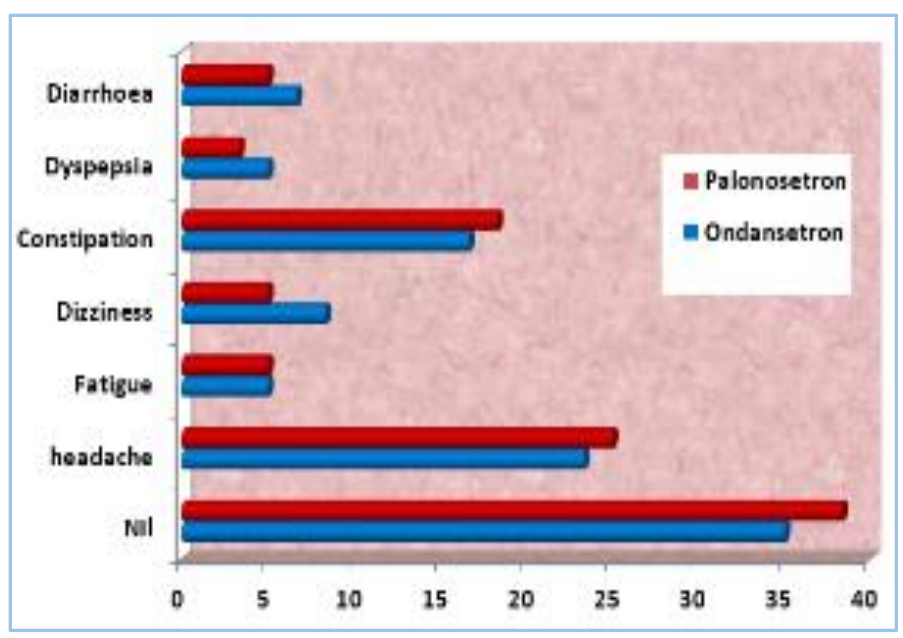

Fig. 7: Comparison of Adverse Effects in $1^{\text {st }}$ Cycle 


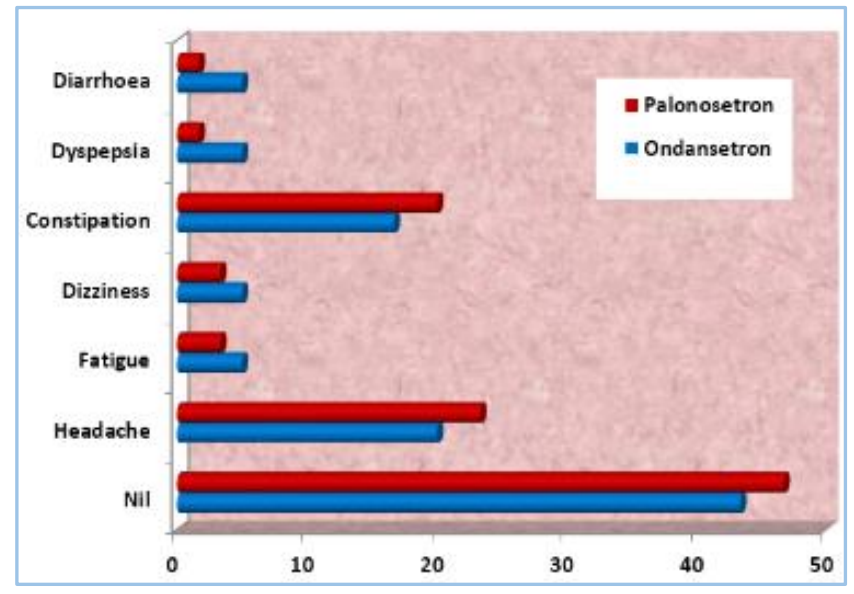

Fig. 8: Comparison of Adverse Effects in $2^{\text {nd }}$ Cycle

Treatment related adverse effects in both the groups were mild and there was no significant difference between two groups (Figures 7 and 8). More commonly reported side effects were headache and constipation.

\section{DISCUSSION}

In this prospective observational study, we have selected the lowest effective dose of Ondansetron (8 $\mathrm{mg})$ and Palonosetron $(0.25 \mathrm{mg})$, both in combination with Dexamethasone $(8 \mathrm{mg}$ ) to determine the most effective and safe, prophylactic antiemetic regimen for Cisplatin-induced emesis in patients attending our tertiary care hospital. Effect of drugs were compared in acute (0-24 hours) and delayed (>24-120 hours) phases of $1^{\text {st }}$ and $2^{\text {nd }}$ cycles of Cisplatin chemotherapy.

Comparison of demographic characteristics of both the groups showed no significant difference between two groups. Palonosetron-Dexamethasone combination provided superior prophylaxis for CINV than OndansetronDexamethasone combination in all phases of chemotherapy. Complete Response rate [CR rate: no emesis and no significant nausea (nausea $<3$ on nausea scale)] of Palonosetron group was significantly higher in delayed phases of both $1^{\text {st }}(73.3 \%$ vs. $50 \%, \mathrm{P}=0.009)$ and $2^{\text {nd }}(78.35$ vs. $55 \%, \mathrm{P}=0.007)$ cycles and in acute phases, even though better responses were seen in Palonosetron group in both the cycles $(70 \%$ vs. $58.3 \%, \mathrm{P}=0.183$ and $71.7 \%$ vs. $61.7 \%$, $\mathrm{P}=0.245$ ), the difference was not statistically significant.

Our study results were consistent with previous study done by Aapro et al, which reported that PalonosetronDexamethasone combination provided significantly higher $\mathrm{CR}$ rate in delayed emesis ( $42 \%$ vs. $28.3 \%) .{ }^{24}$ In a similar study done by Gralla and Colleagues, Palonosetron achieved higher CR rate in acute $(81 \%$ vs. $68.6 \%, \mathrm{P}<0.01)$, delayed $(74.1 \%$ vs. $55.1 \%, \mathrm{P}=0.001)$ and overall phases $(69.3 \%$ vs. $50.3 \%$, $\mathrm{P}<0.001$ ) of CINV after moderately emetogenic chemotherapy. 25

Analysis of patients with nausea and vomiting showed that number of emetic episodes and frequency of nausea were much lower in Palonosetron group compared to Ondansetron group. Number of patients with $>2$ emetic episodes were found to be significantly lower in delayed phases of Palonosetron group in both the cycles $(8.3 \%$ vs. $30 \%, \mathrm{P}=0.003$ and $6.7 \%$ vs. $23.3 \%, \mathrm{P}=0.011$ ). Though we observed lesser control of nausea than vomiting in all cycles for both the groups, compared to Ondansetron-
Dexamethasone combination, Palonosetron-Dexamethasone combination provided better results. Number of patients with severe nausea were much lower in Palonosetron group in all phases and was significantly lower in the delayed phase of $2^{\text {nd }}$ cycle of chemotherapy ( $10 \%$ vs. $26.7 \%, \mathrm{P}=0.018$ ).

When both the groups were compared between 1 st and $2^{\text {nd }}$ cycles for persistence of their antiemetic efficacy, it was seen that there was decreased incidence of vomiting in $2^{\text {nd }}$ cycle compared to $1^{\text {st }}$ cycle. This emphasizes the fact that protection obtained in previous cycles of chemotherapy is one of the most important prognostic factors for CINV and steps to prevent this can definitely improve the quality of life of patients. ${ }^{5,26}$ The incidence of treatment related adverse effects were mild and there was no significant difference between two groups. The more common adverse effects seen were headache and constipation.

Moreover, Palonosetron had the advantage of taking a single dose, which suffice 5 days post-chemotherapy period, whereas Ondansetron had to be administered two to three times daily. The introduction of sustained release tablets of Ondansetron has overcome this drawback to a certain extent, which can provide sustained plasma level of the drug by a single daily dose. It also has the advantage of minimal side effects as rapid and high peak blood levels are not attained. ${ }^{27}$ Main limitation of Palonosetron is its cost, whereas Ondansetron injections and tablets are much cheaper.

\section{CONCLUSION}

This prospective observational study comparing the prophylactic antiemetic efficacy and safety of PalonosetronDexamethasone combination with OndansetronDexamethasone combination demonstrates that Palonosetron provided superior prophylaxis of CINV and significantly higher responses were seen in delayed phase of chemotherapy. The number of emetic episodes and frequency of nausea were also significantly lower for Palonosetron and it has a safety profile similar to that of Ondansetron. Palonosetron thus provides an effective option for delayed onset CINV, which was difficult to manage previously due to limited efficacy of older 5HT3 receptor antagonists like Ondansetron and also had the advantage of taking a single dose, which greatly improves the patient compliance. This study also revealed reduced incidence of CINV in $2^{\text {nd }}$ cycle, compared to $1^{\text {st }}$ cycle of chemotherapy, emphasizing the fact that protection obtained in previous cycles is an important factor to prevent emesis in subsequent cycles.

\section{REFERENCES}

1. Coates A, Abraham S, Kaye S. On the receiving end-patient perception of the side effects of cancer chemotherapy. Eur J Cancer Oncol 1983;19(2):203-8.

2. Rhodes VA, McDaniel RW. Nausea, vomiting, and retching: complex problems in palliative care. CA Cancer J Clin 2001;51(4):232-48.

3. Doherty KM. Closing the gap in prophylactic antiemetic therapy: patient factors in calculating the emetogenic potential of chemotherapy. Clin J Oncol Nurs 1999;3(3):113-9.

4. Osoba D, Zee B, Warr D, et al. Effect of post chemotherapy nausea and vomiting on health-related quality of life the quality of life and symptom control committees of the national cancer institute of canada clinical trials group. Support Care Cancer 1997;5(4):307-13. 
5. Gralla RJ, Osoba D, Kris MG. Recommendations for the use of antiemetics: evidence-based, clinical practice guidelines American society of clinical oncology. J Clin Oncol 1999;17(9):2971-94.

6. Morrow GR, Lindke J, Black PM. Predicting development of anticipatory nausea in cancer patients. J Pain symptom manage 1999;6(4):215-23.

7. Morrow GR, Roscoe JA, Hickok JT. Initial control of chemotherapy-induced nausea and vomiting in patient quality of life. Oncology (Williston Park) 1998;12(3):32-7.

8. Walton SM. Advances in use of the $5-\mathrm{HT}_{3}$ receptor antagonists. Exp Opin Pharmacother 2000;1(2):207-23.

9. Egerer G, Hegenbart U, Salwender HJ. Treatment of chemotherapy-induced emesis supportive care in cancer patients. Recent Developments-Antibiot Chemother 2000;50:171-83.

10. Jantunen IT, Kataja VW, Muhonen TT. An overview of randomised studies comparing $5-\mathrm{HT}_{3}$ receptor antagonists to conventional anti-emetics in the prophylaxis of acute chemotherapy-induced vomiting. Eur J Cancer 1997;33(1):66-74.

11. Hesketh PJ. Comparative review of $5-\mathrm{HT}_{3}$ receptor antagonists in the treatment of acute chemotherapy induced nausea and vomiting. Cancer Invest 2000;18(2):163-73.

12. Hickok JT, Roscoe JA, Morrow GRl. Nausea and emesis remain significant problems of chemotherapy despite prophylaxis with 5-hydroxytryptamine-3 antiemetics. Lancet Oncol 2005;6:765-72.

13. Rudolph M Navari. Pathogenesis-based treatment of chemotherapy-induced nausea and vomiting-two new agents. J Support Oncol 2003;1(2):89-103.

14. Roila F, Fatigoni S. New antiemetic drugs. Ann Oncol 2006;17(2):96-100.

15. De Leon A. Palonosetron (aloxi): a second-generation 5HT (3) receptor antagonist for chemotherapy-induced nausea and vomiting. Proceedings Baylor University Medical Center 2006;19(4):413-6.

16. Rojas C, Slusher BS. Pharmacological mechanisms of 5$\mathrm{HT}_{3}$ and tachykinin $\mathrm{NK}_{1}$ receptor antagonism to prevent chemotherapy-induced nausea and vomiting. Eur J Pharmacol 2012;684(1-3):1-7.

17. Navari RM. Palonosetron: a second generation 5hydroxytryptamine 3 receptor antagonist. Expert Opin Drug Metab Toxicol 2009;5(12):1577-86.
18. Richard J Gralla, David Osoba, Paul J Hesketh. Recommendations for the use of antiemetics: evidence based clinical practice guidelines. ASCO special article J Clin Oncol 1999;17(9):2971-94.

19. Percie du Sert N, Rudd JA, Apfel CC. Cisplatin-induced emesis:systematic review and meta-analysis of the ferret model and the effects of 5-HT3 receptor antagonists. Cancer Chemother Pharmacol 2011;67(3):667-86.

20. Maurie Markman. Progress in preventing chemotherapy induced nausea and vomiting. Cleevland Clinic J Med 2002;69(8):609-10.

21. Ann M Berger, Rebecca A, Clark-Snow. Nausea and Vomiting. In: Vincent T. DeVita Jr. Samuel Hellman editors. Cancer: Principles and Practice of Oncology. $2001 ; 6^{\text {th }}$ ed:2868-77.

22. Kausal J, Gupta MC, Kaushal V, et al. Clinical evaluation of two antiemetic combinations, palonosetron dexamathasone versus ondansetron dexamethasone in chemotherapy of head and neck cancer. Singapore Med J 2010;51(11):871-5.

23. Roila F, Herrstedt J, Aapro M, et al. Guideline update for MASCC and ESMO in the prevention of chemotherapy and radiotherapy-induced nausea and vomiting: results of the perugia consensus conference. Ann Oncol 2010;21(5):232-43.

24. Aapro MS, Bertoli L, Lordic F. Palonosetron is effective in preventing acute and delayed chemotherapy-induced nausea and vomiting in patients receiving highly emetogenic chemotherapy. Support Care Cancer 2003;11(6):391.

25. Gralla R, Lichinitser M, Van der Vegt S, et al. Palonosetron improves prevention of chemotherapy-induced nausea and vomiting following moderately emetogenic chemotherapy: results of a double-blind randomized phase III trial comparing single doses of palonosetron with ondansetron. Ann Oncol 2003;14(10):1570-77.

26. Rusthoven JJ, Osoba D, Butts CA, et al. The impact of postchemotherapy nausea and vomiting on quality of life after moderately emetogenic chemotherapy. Support Care Cancer 1998;6(4):389-95.

27. Sekar Rajan, Socorrina Coalco, Ramesh N, et al. Once daily sustained release tablets of ondansetron, a novel antiemetic. Am J Pharm Tech Res 2013;3(2). 